\title{
Inhibition of repair-related DNA polymerases by vitamin Ks, their related quinone derivatives and associated inflammatory activity (Review)
}

\author{
YOSHIYUKI MIZUSHINA ${ }^{1,2}$, SHIN NISHIUMI $^{3}$, MASAYUKI NISHIDA $^{3}$, \\ HIROMI YOSHIDA $^{1}$, TAKESHI AZUMA ${ }^{3}$ and MASARU YOSHIDA ${ }^{3-5}$
}

\author{
${ }^{1}$ Laboratory of Food and Nutritional Sciences, Department of Nutritional Science, Kobe-Gakuin University, \\ Nishi-ku, Kobe, Hyogo 651-2180; ${ }^{2}$ Cooperative Research Center of Life Sciences, Kobe-Gakuin University, \\ Chuo-ku, Kobe, Hyogo 650-8586; ${ }^{3}$ Division of Gastroenterology, Department of Internal Medicine, \\ ${ }^{4}$ The Integrated Center for Mass Spectrometry and ${ }^{5}$ Division of Metabolomics Research, \\ Kobe University Graduate School of Medicine, Chuo-ku, Kobe, Hyogo 650-0017, Japan
}

Received July 24, 2012; Accepted September 20, 2012

DOI: $10.3892 /$ ijo.2013.1771

\begin{abstract}
Vitamin Ks (VKs) are fat-soluble quinone compounds known to have various bioactivities. This review describes the inflammatory effects of VKs and their related quinone derivatives based on DNA polymerase (pol) inhibition. $\mathrm{VK}_{3}$, but not $\mathrm{VK}_{1}$ or $\mathrm{VK}_{2}(=\mathrm{MK}-4)$, inhibited the activity of human pol $\gamma$, which is the DNA replicative pol in mitochondria. Of the intermediate compounds between $\mathrm{VK}_{2}$ and $\mathrm{VK}_{3}$ (namely MK-3, MK-2 and MK-1), MK-2 was the strongest inhibitor of mammalian pols $\alpha, \kappa$ and $\lambda$, which belong to the B-, Y- and X-families of pols, respectively. Among the $\mathrm{VK}_{3}$ based quinone derivatives, such as 1,4-naphthoquinone (NQ), 2-dimethyl-1,4-naphthoquinone (1,2-dimethyl-NQ), 1,4-benzoquinone (BQ), 9,10-anthraqui-
\end{abstract}

Correspondence to: Dr Yoshiyuki Mizushina, Laboratory of Food and Nutritional Sciences, Department of Nutritional Science, KobeGakuin University, Nishi-ku, Kobe, Hyogo 651-2180, Japan

E-mail: mizushin@nutr.kobegakuin.ac.jp

Dr Masaru Yoshida, Division of Gastroenterology, Department of Internal Medicine, Kobe University Graduate School of Medicine, Chuo-ku, Kobe, Hyogo 650-0017, Japan

E-mail: myoshida@med.kobe-u.ac.jp

Abbreviations: VK, vitamin K; pol, DNA-dependent DNA polymerase (E.C. 2.7.7.7); NQ, 1,4-naphthoquinone; ROS, reactive oxygen species; TdT, terminal deoxynucleotidyl transferase; dTTP, 2'-deoxythymidine-5'-triphosphate; dNTP, 2'-deoxynucleotide-5'triphosphate; $\mathrm{AQ}, 9,10$-anthraquinone; $\mathrm{BQ}, 1$,4-benzoquinone; NCQ, 5,12-naphthacenequinone; $\mathrm{IC}_{50}, 50 \%$ inhibitory concentration; BSA, bovine serum albumin; NF- $\kappa \mathrm{B}$, nuclear factor- $\kappa \mathrm{B}$; TNF- $\alpha$, tumor necrosis factor- $\alpha$; LPS, lipopolysaccharide; BW, body weight; DSS, dextran sulfate sodium; H\&E, hematoxylin and eosin

Key words: DNA polymerase $\lambda$, DNA repair, anti-inflammation, vitamin $\mathrm{K}_{3}$, 1,4-naphthoquinone, enzyme inhibitor none (AQ) and 5,12-naphthacenequinone (NCQ), NQ was the strongest inhibitor of mammalian pols $\alpha$ and $\lambda$, in particular, DNA repair-related pol $\lambda$. Among the all compounds tested, NQ displayed the strongest suppression of tumor necrosis factor (TNF)- $\alpha$ production induced by lipopolysaccharide (LPS) in a cell culture system using RAW264.7 mouse macrophages. NQ also suppressed the expression of pol $\lambda$ protein in these cells, after LPS-treated RAW264.7 cells were stimulated to induce pol $\lambda$ expression. In an in vivo mouse model of LPS-evoked acute inflammation, intraperitoneal injection of NQ into mice suppressed TNF- $\alpha$ production in peritoneal macrophages and serum. In an in vivo colitis mouse model induced using dextran sulfate sodium (DSS), NQ markedly suppressed DSS-evoked colitis. The promising anti-inflammatory candidates based on the inhibition of DNA repair-related pols, such as pol $\lambda$, by VKs quinone derivatives, such as NQ, are discussed.

\section{Contents}

1. Introduction

2. Pol and other DNA metabolic enzyme inhibition by VK quinone derivatives in vitro

3. Effects of VK quinone derivatives on cultured macrophage cells

4. Effects of NQ on inflammation in vivo

5. Discussion

6. Conclusion

\section{Introduction}

Vitamin $\mathrm{K}(\mathrm{VK})$ is a hydrophobic (i.e., insoluble in water) human vitamin. It is needed for the synthesis of proteins required for blood coagulation (1). Normally, VK is produced by bacteria in the intestines and dietary deficiency is extremely rare unless the intestines are badly damaged. VK is essentially involved in the carboxylation of certain glutamate residues 
in proteins to form $\gamma$-carboxyglutamate residues, which are usually involved in binding calcium $(2,3)$. Recently, DNA microarray was used to identify the effect of VK status on gene expression in rat liver. The expression of genes involved in the acute inflammation response was enhanced in rats fed a VK-deficient diet relative to the control and VK-supplemented diet groups (4).

VK comprises a family of structurally similar, fat-soluble 2-methyl-1,4-naphthoquinones, including phylloquinone $\left(\mathrm{VK}_{1}\right)$, menaquinone $\left(\mathrm{VK}_{2}\right)$ and menadione (VK3). The structures are shown in Fig. 1. 1,4-Naphthoquinones (NQs) (compound 7 of Fig. 1) form a family of compounds characterized by a naphthalene ring that contains two carbonyl moieties at positions 1 and 4 and that, in the case of VK, is substituted at positions 2 and 3. All members of the VK family possess an identical NQ skeleton with various isoprenyl chains that distinguish them. $\mathrm{VK}_{1}$ and $\mathrm{VK}_{2}$ differ only in the prosthetic group at position 3 . $\mathrm{VK}_{1}$ possesses a phytyl group (a partially saturated poly-isoprenoid group) at position 3 , whereas $\mathrm{VK}_{2}$ possesses a repeating unsaturated trans-poly-isoprenyl group. The IUPAC-IUB Commission on Biochemical Nomenclature abbreviates $\mathrm{VK}_{2}$ as 'MK-n', where ' $n$ ' signifies the number of unsaturated isoprene units that compose the isoprenyl chain at the 3-position. The isoprenyl chain of MK-n can vary in length from C5 $(n=1)$ to C65 $(n=13)$; for example, menaquinone 4 (MK-4) could also be written as $\mathrm{K}_{2}$ (20). MK-4 $\left(=\mathrm{VK}_{2}\right)$ has three isoprene units plus the first saturated group beginning at position 3 , totaling four (compound 2 of Fig. 1). The most common form of $\mathrm{VK}$ in animals is $\mathrm{VK}_{2}$ in its MK-4 structure, which is produced by intestinal bacteria from exogenous NQs and transformed endogenously in our own cells (5). $\mathrm{VK}_{3}$ possesses a much simpler structure, with no aliphatic chain prosthetic group at position 3 (compound 6 of Fig. 1).

$\mathrm{VK}_{1}$ and $\mathrm{VK}_{2}$ are naturally occurring types of $\mathrm{VK}$. $\mathrm{VK}_{1}$ is synthesized by plants and can be found in such foods as spinach, broccoli, lettuce and soybeans. $\mathrm{VK}_{2}$ is primarily produced by bacteria in the anterior part of the gut and the intestines. The MK-4 and MK-7 forms of $\mathrm{VK}_{2}$ are found in meat, eggs, dairy products and natto, which is fermented food from soybeans. MK-4 is synthesized by animal tissues; other forms of $\mathrm{VK}_{2}$ (mainly MK-7) are synthesized by bacteria during fermentation (6). In natto $0 \%$ of $\mathrm{VK}$ is in the MK-4 form and in cheese $2-7 \%$ is in this form (7). $\mathrm{VK}_{2}$ forms with 2-13 isoprene units, including MK-1, MK-2 and MK-3, have been found in human and animal tissues (8). On the other hand, Booth reported that though $\mathrm{VK}_{2}$ derivatives are synthesized in the intestine, intestinal MKs are not believed to be the primary source of $\mathrm{VK} ; \mathrm{VK}_{1}$ is the primary dietary source; MK-4 and MK-7 are relatively minor sources in the average diet (9). Although $\mathrm{VK}_{3}$ is considered a synthetic analogue, Billeter et al found that $\mathrm{VK}_{1}$ can be cleaved to form $\mathrm{VK}_{3}$ by bacteria in the intestine (10). After absorption, $\mathrm{VK}_{3}$ is thought to become alkylated into biologically active isoprenylated $\mathrm{VK}_{2}$ (11). However, $\mathrm{VK}_{3}$ cannot exert all of the functions of natural $\mathrm{VK}$, a finding that is ascribed to its limited transformation into the fat-soluble vitamin forms $(12,13)$.

VKs have quinone as the principle chemical feature. Quinones are a class of organic compounds that are formally derived from aromatic compounds by exchanging an even number of $-\mathrm{CH}=$ groups by $-\mathrm{C}(=\mathrm{O})$ - groups, with any necessary rearrangement of double bonds, resulting in a fully conjugated cyclic dione structure. The toxicological properties of quinones, which act as alkylating agents, have been examined. For example, quinones are known to interact with flavoproteins to generate reactive oxygen species (ROS) that can induce biological injury (14-17).

In this study, we focus on VKs and their related quinone derivatives and review their possible bioactivity, such as antiinflammatory effects based on the selective inhibition of DNA polymerase [i.e., DNA-dependent DNA polymerase (pol), E.C. 2.7.7.7] species.

\section{Pol and other DNA metabolic enzyme inhibition by VK quinone derivatives in vitro}

Mammalian pol species. Pol catalyzes the polymerization of deoxyribonucleotides alongside a DNA strand, which it 'reads' and uses as a template (18). The newly polymerized molecule is complementary to the template strand and identical to the template's partner strand. Pol can add free nucleotides only to the 3 '-end of the newly formed strand, meaning that elongation of the new strand occurs in a 5'- to -3' direction.

The human genome encodes at least 15 DNA polymerases (pols) that conduct cellular DNA synthesis $(19,20)$. Eukaryotic cells contain 3 replicative pols $(\alpha, \delta$ and $\varepsilon), 1$ mitochondrial pol $(\gamma)$ and at least 11 non-replicative pols $(\beta, \zeta, \eta, \theta, \iota, \kappa, \lambda$, $\mu, v$, terminal deoxynucleotidyl transferase (TdT) and REV1) $(21,22)$. Pols have a highly conserved structure, which means that their overall catalytic subunits show little variance among species. Enzymes with conserved structures usually perform important cellular functions, the maintenance of which provides evolutionary advantages. On the basis of sequence homology, eukaryotic pols can be divided into 4 main families, termed A, B, X and Y (22). Family A includes mitochondrial pol $\gamma$, as well as pols $\theta$ and $\nu$. Family B includes 3 replicative pols $(\alpha, \delta$ and $\varepsilon$ ) and pol $\zeta$. Family X comprises pols $\beta, \lambda$ and $\mu$, as well as TdT; lastly, family $\mathrm{Y}$ includes pols $\eta, \mathrm{\iota}$ and $\kappa$, in addition to REV1.

An assay method to detect pol inhibitors has been established $(23,24)$. The substrates of the pols were synthesized DNA, such as poly $(\mathrm{dA}) /$ oligo $(\mathrm{dT})_{18}(\mathrm{~A} / \mathrm{T}=2 / 1)$ and tritiumlabeled 2'-deoxythymidine 5'-triphosphate $\left(\left[{ }^{3} \mathrm{H}\right]\right.$-dTTP) as DNA template-primer substrate and nucleotide [2'-deoxynucleotide 5'-triphosphate (dNTP)] substrate, respectively. The $\left[{ }^{3} \mathrm{H}\right]$-dTTP incorporated radioactive DNA products were collected on DEAE-cellulose paper discs and radioactivity was measured in a scintillation counter. Activity without the inhibitor was considered $100 \%$ and the remaining activity at each concentration of the inhibitor was determined relative to this value. One unit of pol activity was defined as the amount of enzyme that catalyzed the incorporation of $1 \mathrm{nmol} \mathrm{dNTP}$ (i.e., dTTP) into synthetic DNA template-primers in $60 \mathrm{~min}$ at $37^{\circ} \mathrm{C}$ under the normal reaction conditions for each enzyme. Pols from mammal, fish, insect and plant, which were purified and have high activity, were prepared according to previous reports $(25)$.

Effect of VK quinone derivatives on mammalian pol activity. Although many researchers found and reported inhibitors against all eukaryotic pol species, mainly nucleotide analogues, we have been studying selective inhibitors of each mammalian pol derived from natural products, including food materials and 


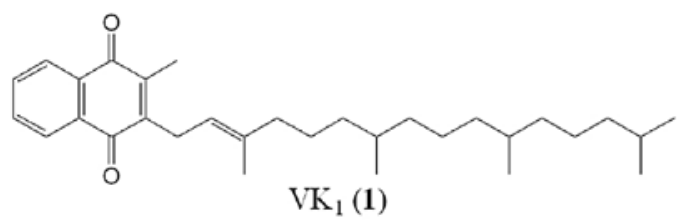<smiles>CC(C)=CCC/C(C)=C/CC/C([As])=C/CC/C([Y16]#N)=C\CC1=C(C)C(=O)c2ccccc2C1=O</smiles><smiles>CC(C)=CCC/C(C)=C/CC/C(=C/CC1=C(C)C(=O)c2ccccc2C1=O)[As]=[W]</smiles><smiles>CC(C)=CCC/C([14CH3])=C/CC1=C(C)C(=O)c2ccccc2C1=O</smiles><smiles>CC(C)=CCC1=C(C)C(=O)c2ccccc2C1=[W]</smiles><smiles>CC1CC(=O)c2ccccc2C1=O</smiles>
$\mathrm{VK}_{3}(=1-$-methyl NQ) (6)<smiles>O=C1C=CC(=O)c2ccccc21</smiles><smiles>CCC1=C(C)C(=O)c2ccccc2C1=O</smiles>
1,2-dimethyl NQ (8)<smiles>O=C1C=CC(=O)C=C1</smiles><smiles></smiles><smiles></smiles>

Figure 1. Structures of VKs and their related quinone derivatives. 1, Vitamin $\mathrm{K}_{1}\left(\mathrm{VK}_{1}\right) ; 2$, Vitamin $\mathrm{K}_{2}\left(\mathrm{VK}_{2}=\mathrm{MK}-4\right)$; 3, MK-3; 4, MK-2; 5, MK-1; 6, Vitamin $\mathrm{K}_{3}$ $\left(\mathrm{VK}_{3}=\right.$ 1-methyl-NQ); 7, 1,4-naphthoquinone (NQ); 8, 1,2-dimethyl-1,4-naphthoquinone (1,2-dimethyl-NQ); 9, benzoquinone (BQ); 10, 9,10-anthraquinone (AQ) and 11, 5,12-naphthacenequinone (NCQ).

nutrients, for more than 15 years (26-28). In fat-soluble vitamins, $\mathrm{VK}_{3}$, but not $\mathrm{VK}_{1}$ or $\mathrm{VK}_{2}$, is a potent and specific inhibitor of human pol $\gamma$ (29-33). Therefore, in this review, VKs and their related quinone derivatives, which are the 11 compounds in Fig. 1, were the focus.

The inhibition of the biochemical action of four mammalian pols, namely calf pol $\alpha$, human pol $\gamma$, human pol $\kappa$ and human pol $\lambda$, induced by the administration of $50 \mu \mathrm{M}$ of each compound, was investigated in vitro (34-36). Pols $\alpha, \gamma, \kappa$ and $\lambda$ were used as representatives of the B-, A-, Y- and X-families of pols, respectively (19-21). As shown in Fig. 2, MK-3, MK-2 and MK-1, which are chemically synthesized intermediates between $\mathrm{VK}_{2}$ and $\mathrm{VK}_{3}$, inhibited the activity of mammalian pols $\alpha, \kappa$ and $\lambda$, whereas $\mathrm{VK}_{2}(=\mathrm{MK}-4)$ and $\mathrm{VK}_{1}$ had no effect on pol activity. $\mathrm{VK}_{3}$ selectively inhibited pol $\gamma$ among the mammalian pols tested. Among compounds 1-6 in Fig. 1, the inhibitory effect of these compounds on pols $\alpha, \kappa$ and $\lambda$ ranked as follows: $\mathrm{MK}-2>\mathrm{MK}-1>\mathrm{MK}-3>\mathrm{VK}_{1}=\mathrm{VK}_{2}=\mathrm{VK}_{3}$; and the inhibitory effect of these compounds on pol $\gamma$ ranked as follows: $\mathrm{VK}_{3}>\mathrm{MK}-1>\mathrm{MK}-2>\mathrm{MK}-3>\mathrm{VK}_{1}=\mathrm{VK}_{2}$. The $50 \%$ inhibitory concentration $\left(\mathrm{IC}_{50}\right)$ values of MK-2 against pols $\alpha, \gamma, \kappa$ and $\lambda$ were 27.6, 68.8, 35.3 and $24.6 \mu \mathrm{M}$, respectively (34).
Of the $\mathrm{VK}_{3}$ based quinone compounds 6-11, NQ and 1,4-benzoquinone (BQ) most strongly inhibited the activities of pols $\alpha$ and $\lambda$, but other compounds did not have an influence. $\mathrm{VK}_{3}$ (1-methyl-NQ) and 1,2-methyl-NQ selectively suppressed pol $\gamma$ activity among the mammalian pols tested and $\mathrm{VK}_{3}$ was a stronger pol $\gamma$ inhibitor than 1,2-methyl-NQ. By contrast, 9,10-anthraquinone (AQ) and 5,12-naphthacenequinone (NCQ) had no effect on the activities of these pols. The inhibitory effects of the 11 compounds on the activities of pols $\alpha$ and $\lambda$ were ranked as follows: $\mathrm{NQ}>\mathrm{BQ}>\mathrm{MK}-2>\mathrm{MK}-1>\mathrm{MK}-3>\mathrm{VK}_{1}=\mathrm{VK}_{2}=$ $\mathrm{VK}_{3}=1,2-$ methyl-NQ $=\mathrm{AQ}=\mathrm{NCQ}$.

When activated DNA, via DNA digestion by bovine deoxyribonuclease I and dNTP were used as the DNA template-primer and nucleotide substrate, respectively, instead of poly(dA)/ oligo $(\mathrm{dT})_{18}(\mathrm{~A} / \mathrm{T}=2 / 1)$ and $\mathrm{dTTP}$, respectively, the mode of inhibition by these compounds did not change (34-36).

Effect of $N Q$ on pols and other DNA metabolic enzymes. Among the VKs and their related quinone derivatives investigated, NQ displayed the strongest inhibitory effect on mammalian pols $\alpha$ and $\lambda$ (Fig. 2) and is therefore the focus of this section. As described briefly in the previous section, ten 


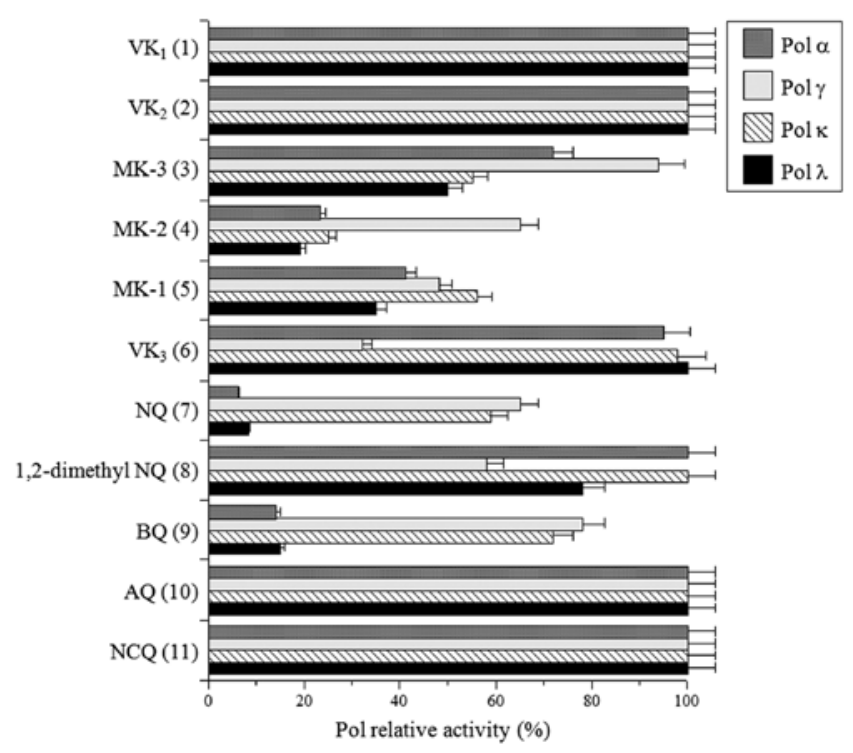

Figure 2. Inhibitory effects of VKs and their related quinone derivatives on the activity of mammalian pols. Each compound $(50 \mu \mathrm{M})$ was incubated with calf pol $\alpha$ (B-family pol), human pol $\gamma$ (A-family pol), human pol $\kappa$ (Y-family pol) and human pol $\lambda$ (X-family pol) ( $0.05 \mathrm{U}$ each). Pol activity in the absence of the compound was taken as $100 \%$ and the relative activity is shown. Data are shown as the mean $\pm S E(n=3)$.

mammalian pol species including pols $\alpha, \beta, \gamma, \delta, \varepsilon, \mathrm{l}, \eta, \kappa$ and $\lambda$ and TdT are obtainable; however, pols $\zeta, \theta, \mu, v$ and REV1 are not yet available (Table I). Currently, eukaryotes are thought to express at least 15 species of pols $(19,20)$ and we are still in an era when most pols are very difficult to obtain in purified form in a laboratory. Table I shows the inhibitory effect ( $\mathrm{IC}_{50}$ value) of NQ against various pol species including the ten eukaryotic pols that can be obtained (35). This compound inhibited the activity of all of the pols from mammals and $50 \%$ inhibition of the A-, B-, X- and Y-families of pols was observed at a dose of 73.0, 6.65-67.2, 5.57-128 and 68.2-72.0 $\mu \mathrm{M}$, respectively. Calf pol $\alpha$ and human pol $\lambda$ were inhibited most strongly in the B- and X-families, respectively. These results suggested that the strength of the inhibitory effect of NQ on mammalian pol families can be ranked as follows: B-family pols = X-family pols $>$ A-family pols = Y-family pol. NQ showed the strongest inhibition of pol $\lambda$ activity among the pols investigated, with an $\mathrm{IC}_{50}$ value of $5.57 \mu \mathrm{M}$. This compound also inhibited the activity of the animal pols from fish (cherry salmon) and insect (fruit fly) at almost the same concentrations that inhibited the activity of mammalian pols (35).

By contrast, NQ had minimal influence on the activity of plant (cauliflower) pol $\alpha$ or prokaryotic pols, such as E. coli pol I, Taq pol, or T4 pol (Table I) (35). The three-dimensional structures of eukaryotic pols are likely to differ greatly from those of prokaryotic pols $(18,19)$. NQ did not inhibit the activity of other DNA metabolic enzymes, such as calf primase pol $\alpha$, T7 RNA polymerase, T4 polynucleotide kinase, or bovine deoxyribonuclease I. These results suggest that NQ may be a selective inhibitor of animal pols, especially the B-and $\mathrm{X}$-families of pols containing pol $\lambda$.

To test whether NQ-induced inhibition resulted from the ability of this compound to bind to DNA or to the enzyme,
Table I. $\mathrm{IC}_{50}$ values of NQ on the activities of various pols and other DNA metabolic enzymes.

\begin{tabular}{ll}
\hline Enzyme & $\begin{array}{l}\mathrm{IC}_{50} \text { value o } \\
\mathrm{NQ}(7)(\mu \mathrm{M})\end{array}$ \\
\hline Mammalian DNA polymerases & \\
A-Family & $73.0 \pm 3.7$ \\
$\quad$ Human DNA polymerase $\gamma$ & \\
B-Family & $6.65 \pm 0.35$ \\
Calf DNA polymerase $\alpha$ & $67.2 \pm 3.5$ \\
Human DNA polymerase $\delta$ & $61.4 \pm 3.2$ \\
Human DNA polymerase $\varepsilon$ & \\
X-Family & $128 \pm 6.4$ \\
Rat DNA polymerase $\beta$ & $5.57 \pm 0.28$ \\
Human DNA polymerase $\lambda$ & $55.6 \pm 2.88$ \\
Calf terminal deoxynucleotidyl transferase & \\
Y-Family & $72.0 \pm 4.2$ \\
Human DNA polymerase $\eta$ & $70.2 \pm 4.0$ \\
Mouse DNA polymerase $\iota$ & $68.2 \pm 3.9$ \\
Human DNA polymerase $\kappa$ &
\end{tabular}

Fish DNA polymerases

B-Family

Cherry salmon DNA polymerase $\delta$

$68.4 \pm 3.5$

Insect DNA polymerases

B-Family

Fruit fly DNA polymerase $\alpha$

$8.30 \pm 0.38$

Fruit fly DNA polymerase $\delta$

$69.5 \pm 3.7$

Fruit fly DNA polymerase $\varepsilon$

$64.1 \pm 3.4$

Plant DNA polymerases -

B-Family

Cauliflower DNA polymerase $\alpha \quad>100$

Prokaryotic DNA polymerases

E. coli DNA polymerase I $\quad>100$

Taq DNA polymerase $\quad>100$

T4 DNA polymerase $\quad>100$

Other DNA metabolic enzymes

Calf primase of DNA polymerase $\alpha \quad>100$

T7 RNA polymerase $\quad>100$

T4 polynucleotide kinase $\quad>100$

Bovine deoxyribonuclease I $\quad>100$

NQ was incubated with each enzyme. Enzyme activity in the absence of the compound was taken as $100 \%$. Data are shown as the mean $\pm \operatorname{SE}(n=3)$.

the thermal transition of DNA in the presence or absence of NQ was measured (35). The interaction of NQ with dsDNA was investigated based on the thermal transition of dsDNA 
by measuring the melting temperature (Tm) of dsDNA with an excess amount of NQ (100 $\mu \mathrm{M}$ each) using a spectrophotometer equipped with a thermoelectric cell holder. A thermal transition of Tm was not observed within the concentration range of the compound used in the assay, whereas a typical intercalating compound used as a positive control (ethidium bromide, $15 \mu \mathrm{M}$ ) produced a clear thermal transition. It also was investigated whether an excessive amount of nucleic acid [poly(rC)] or protein [bovine serum albumin (BSA)] prevented the inhibitory effect of NQ to determine whether the inhibitory effect resulted from non-specific adhesion of these molecules to animal pols, or from selective binding to specific sites (35). Poly(rC) and BSA had little or no influence on the pol inhibitory effect of NQ, suggesting that this compound selectively binds to the target enzyme molecule. These observations indicated that NQ does not act as a DNA intercalating agent or a DNA template-primer substrate, but that this compound can directly bind to the enzyme and inhibit its activity. Collectively, these results suggest that NQ may be a potent and specific inhibitor of animal pols, especially pol $\lambda$.

\section{Effects of VK quinone derivatives on cultured macro- phage cells}

In many inflammatory responses, activation of nuclear factor $(\mathrm{NF})-\kappa \mathrm{B}$ is the rate-limiting step of the inflammatory mechanism (37). The five members of the mammalian NF- $\mathrm{B}$ family, namely p65 (RelA), RelB, c-Rel, p50/p105 (NF-кB1) and p52/ p100 (NF- $\kappa \mathrm{B} 2)$, exist in unstimulated cells as homodimers or heterodimers bound to proteins of the I $\mathrm{B}$ family (38). The binding of $N F-\kappa B$ to $\mathrm{I} \kappa \mathrm{B}$ prevents $N F-\kappa \mathrm{B}$ from translocating to the nucleus, thereby maintaining $N F-\kappa B$ in an inactive state. $\mathrm{NF}-\kappa \mathrm{B}$ proteins are characterized by the presence of a conserved 300-amino-acid Rel homology domain located in the N-terminus of the protein and this domain is responsible for dimerization with $\mathrm{NF}-\kappa \mathrm{B}$, interaction with $\mathrm{I} \kappa \mathrm{B}$ and binding to DNA (38). The translocated NF- $\kappa$ B proteins work as transcription factors and regulate the expression of various genes that encode proinflammatory cytokines such as tumor necrosis factor (TNF)- $\alpha$ and interleukin (IL)-12, which have been shown to play important roles in sustained inflammatory responses (39-41).

Effect of VK quinone derivatives on LPS-induced TNF- $\alpha$ production. Next, it was investigated whether VKs and their related quinone derivatives can inhibit the inflammatory response in cultured mouse macrophage RAW264.7 cells treated with lipopolysaccharide (LPS), which stimulates macrophages to release inflammatory cytokines such as TNF- $\alpha$ (34-36). The cells were placed in a 12-well plate at a concentration of $5 \times 10^{4}$ cells/well and incubated for $24 \mathrm{~h}$. The cells were pre-treated with each compound (final concentrations of 5 and $10 \mu \mathrm{M}$ ) for $30 \mathrm{~min}$ before the addition of $100 \mathrm{ng} / \mathrm{ml}$ of LPS. After stimulation with LPS for $24 \mathrm{~h}$, the cell culture medium was collected to measure the amount of TNF- $\alpha$ secreted. The concentration of TNF- $\alpha$ in the culture medium was quantified by using a commercially available enzyme-linked immunosorbent assay (ELISA) development system.

In RAW264.7 cells, no compound showed cytotoxicity at $10 \mu \mathrm{M}$ because the $50 \%$ lethal dose $\left(\mathrm{LD}_{50}\right)$ values of these

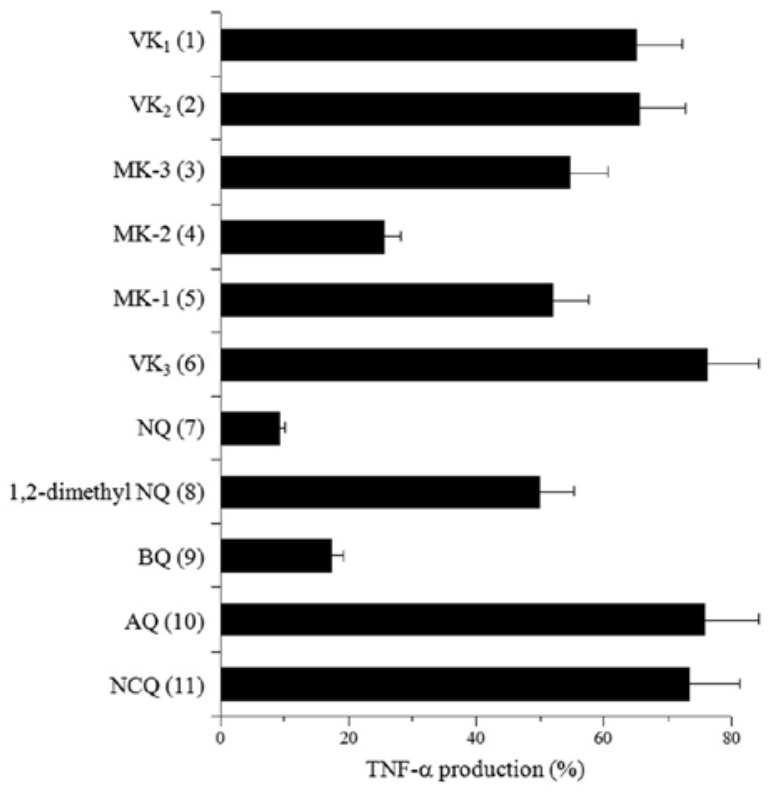

Figure 3. Inhibitory effects of VKs and their related quinone derivatives on LPS-induced production of TNF- $\alpha$ in the mouse macrophage cell line RAW264.7. These cells were pretreated with $10 \mu \mathrm{M}$ of each compound as a vehicle control for $30 \mathrm{~min}$ and then treated with $100 \mathrm{ng} / \mathrm{mL} \mathrm{LPS} \mathrm{for} 24 \mathrm{~h}$. The TNF- $\alpha$ concentration in the cell medium was measured by ELISA. The relative effect in the absence of the compound was taken as $100 \%$. Data are shown as the mean $\pm \operatorname{SE}(n=4)$.

eleven compounds were $>10 \mu \mathrm{M}$ (34-36). Among VKs and the $\mathrm{VK}_{2}-\mathrm{VK}_{3}$ intermediates (i.e., compounds 1-6), MK-2 at $10 \mu \mathrm{M}$ significantly suppressed the LPS-stimulated production of TNF- $\alpha$ and other compounds hardly suppressed (Fig. 3). In the $\mathrm{VK}_{3}$ related quinone compounds (i.e., compounds 6-11), NQ and $\mathrm{BQ}$ at $10 \mu \mathrm{M}$ were potent suppressors of TNF- $\alpha$ production and 1,2-dimethyl NQ moderately suppressed TNF- $\alpha$ production. By contrast, $\mathrm{VK}_{3}, \mathrm{AQ}$ and NCQ displayed hardly any effect on TNF- $\alpha$ production. The inhibitory effects of NQ and BQ were, respectively, the first and second strongest among these 11 compounds tested; the order of this effect was NQ $>\mathrm{BQ}>$ MK-2 $>$ MK-3 = MK-1 = 1,2-dimethyl-NQ $>\mathrm{VK}_{1}=\mathrm{VK}_{2}=\mathrm{VK}_{3}$ $=\mathrm{AQ}=\mathrm{NCQ}$. The effect of these compounds on the suppression of LPS-evoked TNF- $\alpha$ production showed almost the same tendency as the inhibitory effect on mammalian pols $\alpha$ and $\lambda$. These results suggest that VKs and their related quinone derivatives, such as NQ, might inhibit the activities of mammalian pols and then prevent the production of TNF- $\alpha$ in LPS-induced macrophages, but not affect the cell growth.

Effect of NQ on LPS-induced pols expression and inflammatory response. Because there was a relationship between the in vitro pols $\alpha$ and $\lambda$ inhibition and LPS-induced TNF- $\alpha$ suppression in cultured mouse macrophage RAW264.7 cells by VK quinone derivatives, the effect of NQ, the strongest pols $\alpha$ and $\lambda$ inhibitor and TNF- $\alpha$ suppressor, on the inflammatory response in the cells was investigated (Mizushina et al, unpublished data). RAW264.7 cells in a 6-well plate at a concentration of $5 \times 10^{5}$ cells/well were incubated with $10 \mu \mathrm{M}$ of NQ or DMSO as a vehicle control for $30 \mathrm{~min}$, followed by treatment with $100 \mathrm{ng} / \mathrm{ml}$ of LPS for $30 \mathrm{~min}$. After treatment, cells were harvested and the nuclear protein extract was prepared. The protein concentration of each extract 


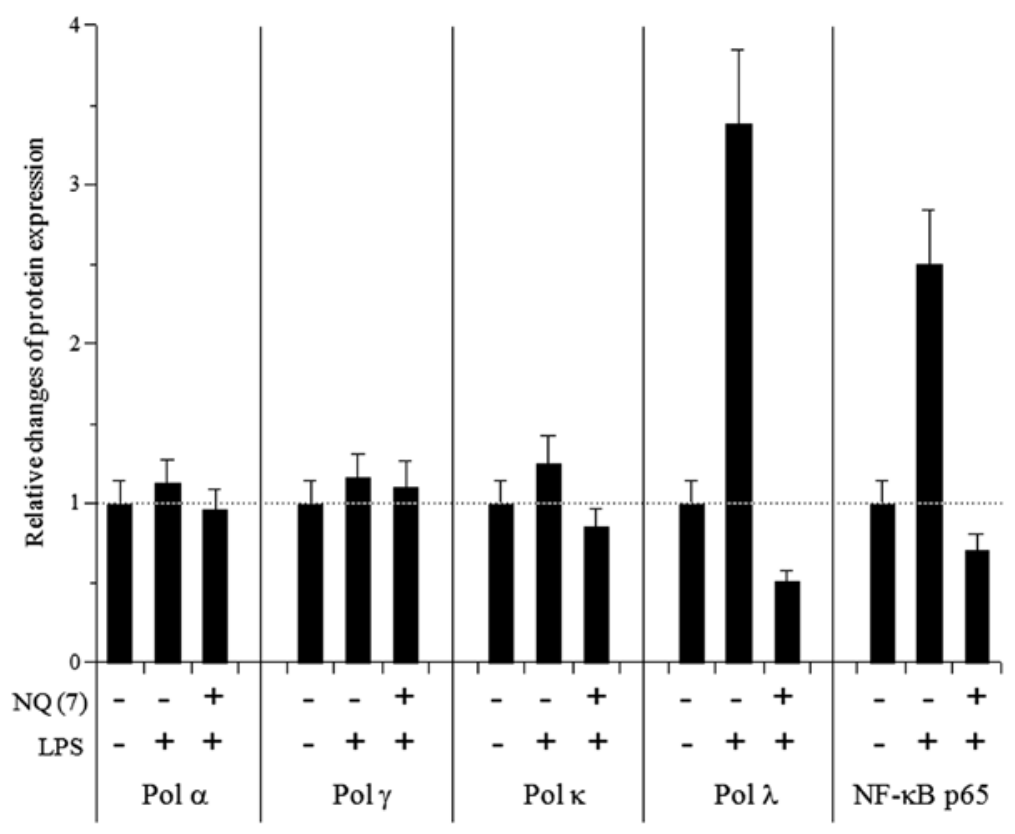

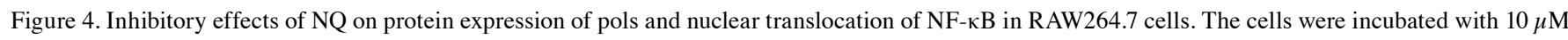
NQ (+) or DMSO (-), as a vehicle control, for $30 \mathrm{~min}$ and then with $100 \mathrm{ng} / \mathrm{ml}$ LPS for $30 \mathrm{~min}$. Nuclear proteins were prepared from the cells and subjected to western blot analysis for evaluation of pols $\alpha, \gamma, \kappa$ and $\lambda$ and the nuclear translocation of NF- $\mathrm{KB}$ p65. The intensity of each band was analyzed and the values relative to treatment without LPS (negative control, taken as 1.0-fold) are represented at the lower edge of the image. Data are shown as the mean \pm SE ( $\mathrm{n}=3$ ).

was obtained and the amount of the $\beta$-actin band was used as a control in western blotting.

First, the effect of NQ on the protein expression level of pols $\alpha, \gamma, \kappa$ and $\lambda$ in LPS-treated RAW264.7 cells was measured using western blotting. As shown in Fig. 4, these macrophages underwent a more than 3 -fold increase in the expression of pol $\lambda$ after LPS stimulation, but that this increase was significantly suppressed by $10 \mu \mathrm{M}$ NQ. By contrast, the protein expression levels of other mammalian pols, including pol $\alpha$, were not influenced by LPS and NQ. These results suggest that there is a positive correlation between inflammatory induction by LPS and pol $\lambda$ expression; thus, not only the DNA polymerization activity, but also the protein expression of DNA repair-related pol $\lambda$ is likely to be important in inflammation.

The inflammatory cytokine TNF- $\alpha$ activates the NF- $\kappa \mathrm{B}$ signaling pathway by binding to the TNF- $\alpha$ receptor (TNFR) and thereby initiates an inflammatory response, resulting in various inflammatory diseases (42). Therefore, the inhibitory effect of NQ on the LPS-induced nuclear translocation of $\mathrm{NF}-\kappa \mathrm{B}$ in RAW264.7 cells was examined. Using western blot analysis, it was revealed that the amount of NF- $\kappa \mathrm{B}$ nuclear translocation in RAW264.7 cells was 2.5-fold greater after LPS treatment and that $10 \mu \mathrm{M}$ NQ was sufficient to inhibit the LPS-stimulated nuclear translocation of NF- $\mathrm{B}$ by 0.7 -fold (Fig. 4). These results demonstrate that this compound can strongly suppress the nuclear translocation of $\mathrm{NF}-\kappa \mathrm{B}$ by inhibiting the production of TNF- $\alpha$.

Anti-oxidative activity has been reported to be linked to anti-inflammatory activity (43); therefore, the anti-oxidative activity of NQ against the production of ROS induced by TNF- $\alpha$ was investigated according to the method of a previous report (44). In RAW264.7 cells, at $10 \mu \mathrm{M}$, NQ decreased the production of ROS induced by $50 \mathrm{ng} / \mathrm{ml}$ of TNF- $\alpha$ to $49.2 \%$, suggesting that this compound possesses anti-oxidative activity (Mizushina et al, unpublished data).

\section{Effects of NQ on inflammation in vivo}

Effect of NQ on LPS-induced mouse inflammation. To assess the anti-inflammatory effects of NQ in vivo, the inhibitory activity of this compound against LPS-induced acute inflammation was investigated (35). Treatment with $250 \mu \mathrm{g} / \mathrm{kg}$ body weight (BW) of LPS significantly increased the serum TNF- $\alpha$ level $(5 \mathrm{ng} / \mathrm{ml})$ and intraperitoneal injection of $20 \mathrm{mg} / \mathrm{kg} \mathrm{BW}$ of NQ strongly decreased this LPS-induced TNF- $\alpha$ production to $92.1 \%$. Thus, the in vivo data obtained in the mouse study gave the same trend as the data obtained from cultured mouse macrophage cells.

Effect of NQ on DSS-induced colitis in mice. To evaluate the therapeutic effects of NQ on colitis, a dextran sulfate sodium (DSS)-induced colitis mouse model was used (36). DSS is a sulfate polysaccharide that has been very widely used to induce inflammation in experimental models of inflammatory bowel disease $(45,46)$. The $2.5 \%$ (wt/vol) DSS-treated C57BL/6J mice were injected orally with either NQ at $20 \mathrm{mg} / \mathrm{kg}$ BW or corn oil as a vehicle control once daily (total 4 oral injections) and then were sacrificed. During the experiment, the BW of the mice was measured daily and the relative BW was calculated as the BW of a mouse on Day 12 relative to the initial BW of the same mouse on Day 0.

As a result, it was found that NQ significantly improved the decreased BW of the colitis mice. This compound also reduced the DSS-induced shortening of colon length. In a histopathological examination with hematoxylin and eosin (H\&E) staining (Fig. 5A), NQ attenuated the degree of tissue 
A

C
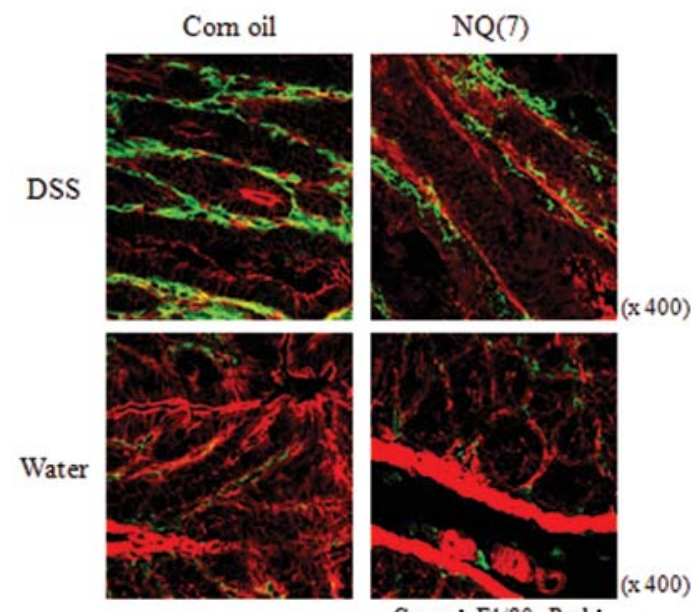

Green: F4/80 Red:

phalloidin
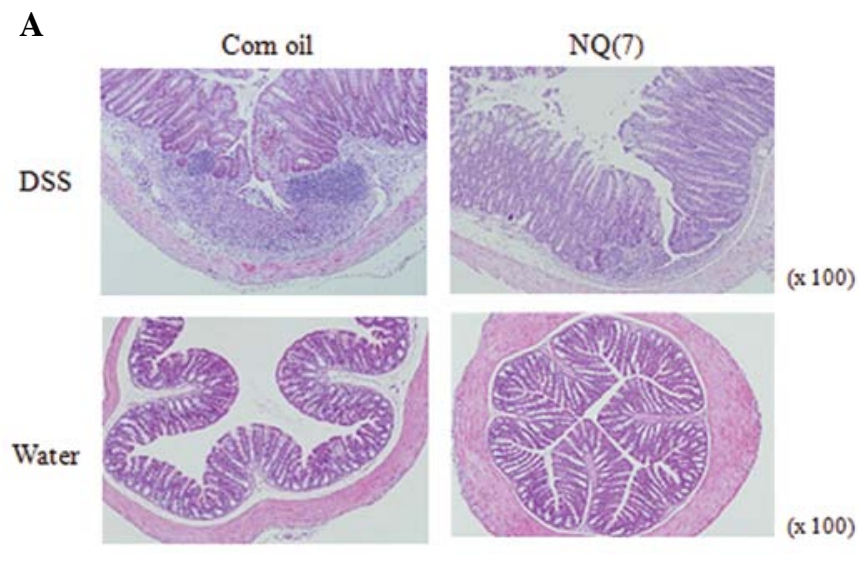

B

$(x 100)$ $(x$ 100) $x$ 400)

(n)

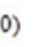
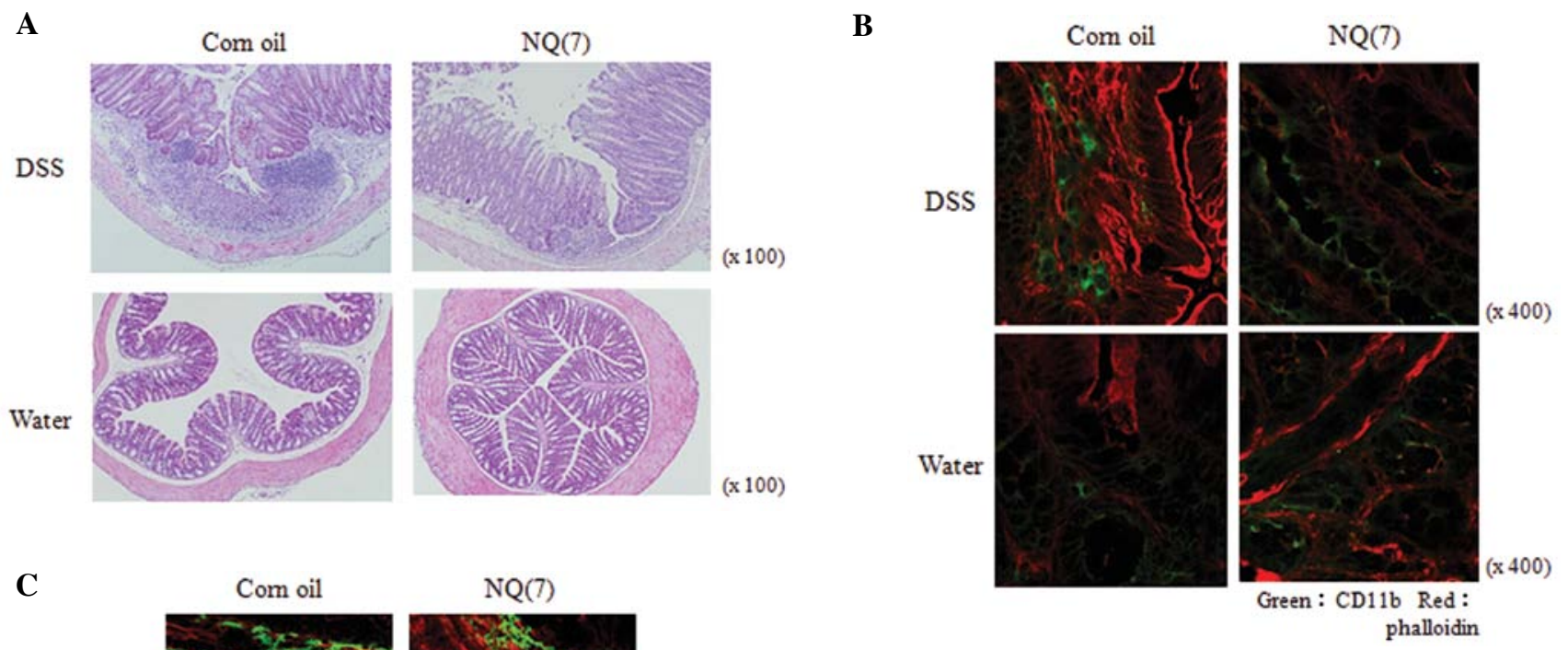

Figure 5. Inhibitory effects of NQ on DSS-induced colitis in mice. Colitis was induced in mice by the administration of DSS. C57BL/6J mice were administered 2.5\% (wt/vol) DSS in their drinking water for 5 days (Day 0-5) and subsequently were given drinking water alone. The mice were orally injected with NQ at $20 \mathrm{mg} / \mathrm{kg} \mathrm{BW}$ or corn oil as a vehicle control once daily from Day 8-11 (a total of 4 oral injections) and then the mice were sacrificed at Day 12. (A) Histopathological evaluation of the colon tissue of mice challenged with DSS and NQ. H\&E staining was performed using colon sections obtained from mice treated with DSS and NQ (upper) or water alone and NQ (lower). Magnification x100. (B and C) Immunohistochemical staining in mice challenged with DSS and NQ. Frozen colon tissue obtained from mice treated with DSS and NQ (upper) or water alone and NQ (lower) was stained with anti-CD11b antibody (B) and anti-F4/80 antibody (C). The frozen tissue also was stained with Alexa Fluor 546-labeled phalloidin to observe the form of the colon tissue. The green and red signals represent CD11b and F4/80 or phalloidin, respectively. Magnification x400.

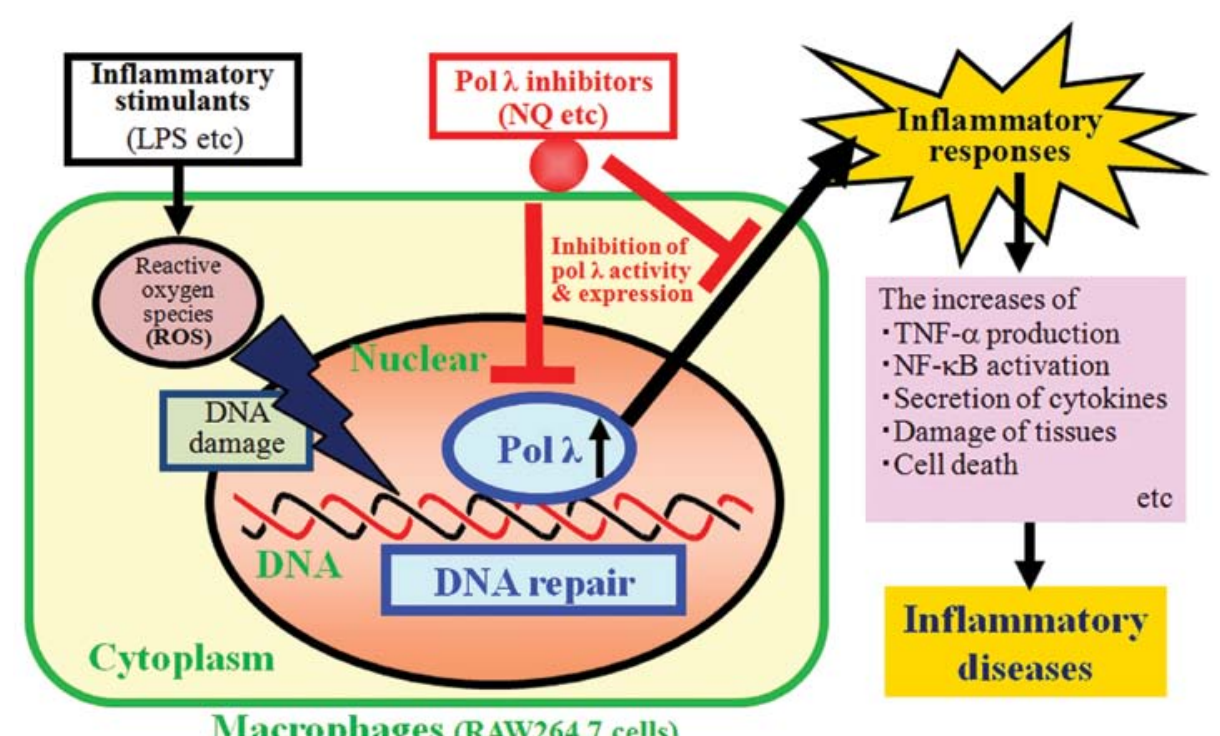

Figure 6 . The relationship between DNA repair by pol $\lambda$ and inflammation.

injury induced by DSS. RNA was isolated from the colon epithelia of mice treated with DSS and NQ and the expression levels of TNF- $\alpha$ mRNA were examined by quantitative real-time PCR. In DSS-induced colitis mice, the expression level of TNF- $\alpha$ mRNA was elevated and the administration of NQ led to a reduction in TNF- $\alpha$ production in the colon epithelium. The frozen colon sections obtained from the mice were stained with anti-CD11b antibody to detect monocytes including macrophages (Fig. 5B) and anti-F4/80 antibody to detect macrophages (Fig. 5C). As a result, it was found that 
NQ significantly attenuated macrophage infiltration into the large intestinal submucosa of the mice; therefore, NQ might be useful as a therapeutic anti-inflammatory drug.

\section{Discussion}

The relationship between the bioactivity and the structures of $V K$ quinone derivatives. This review described the bioactivities of VKs and their quinone derivatives of compounds 1-11 in Fig. 1. Among the intermediates between $\mathrm{VK}_{2}(\mathrm{MK}-4)$ and $\mathrm{VK}_{3}$, such as compounds 2-6, MK-2 showed the strongest effects on inhibition of mammalian pols $\alpha$ and $\lambda$ and LSP-induced TNF- $\alpha$ prevention in the inflammatory response (Figs. 2 and 3); therefore, the length of the isoprenyl chain of MK-n at the 3-position of $\mathrm{VK}_{2}$ is essential for these inhibitory activities. On the other hand, NQ showed the strongest of these effects among all 11 compounds tested. $\mathrm{NQ}, \mathrm{VK}_{3}$ and 1,2-dimethylNQ have none, one and two methyl groups in addition to their NQ backbone, respectively. BQ, NQ, AQ and NCQ consist of a polycyclic aromatic hydrocarbon, such as benzene, naphthalene, anthracene, or tetracence, respectively and these compounds are four major quinone derivatives that have two ketone groups at positions 1 and 4 . Thus, the quinone ring structure based on $\mathrm{NQ}$, which has no methyl side group, must be very important for the bioactivity. As reported previously, the phenolic compound curcumin, which is a known anti-inflammatory agent, is a pol- $\lambda$-specific inhibitor $(27,47,48)$. Intriguingly, pol $\lambda$ is also the principle molecular target of VKs and their quinone derivatives based on NQ.

DNA repair-related pol inhibition and anti-inflammation. Inflammatory mediators, such as LPS and DSS, quickly stimulate ROS (46) and ROS are known to mediate oxidative DNA damage. As shown in Fig. 6, DNA repair pols such as pol $\lambda$ induce protein expression and increase DNA polymerization activity to repair the damaged DNA. Furthermore, we consider that pol $\lambda$ might have a great effect on inflammatory responses, such as TNF- $\alpha$ production, NF- $\mathrm{KB}$ activation, secretion of cytokines [e.g. interferons and interleukins], tissue damage and cell death. The results summarized in this review suggest that inhibition of DNA repair by pol $\lambda$ is related to antiinflammatory pathways and that pol $\lambda$ inhibitors such as NQ might be chemotherapeutic drugs for inflammatory diseases. The detailed molecular mechanism underlying the correlation between DNA repair inhibition by pol $\lambda$ and anti-inflammatory responses is not yet known; therefore, experiments with small interfering RNA (siRNA) targeting pol $\lambda$ would help in further analyses.

As mentioned above, eukaryotic cells reportedly contain 15 pol species belonging to four families $(3,4)$. Among the X-family of pols, pol $\lambda$ has an unclear biochemical function, although it seems to work in a similar way to pol $\beta$ (49). Pol $\beta$ is involved in the short-patch base excision repair (BER) pathway (50-53), as well as playing an essential role in neural development (54). Pol $\lambda$ was found to possess 5'-deoxyribose-5-phosphate (dRP) lyase activity, but not apurinic/apyrimidinic (AP) lyase activity (55). Pol $\lambda$ is able to substitute for pol $\beta$ during in vitro BER, suggesting that pol $\lambda$ also participates in BER. Northern blot analysis indicated that transcripts of pol $\beta$ are abundantly expressed in the testis, thymus and brain in rats (56), whereas pol $\lambda$ is efficiently transcribed mostly in the testis (57). Bertocci et al reported that mice in which pol $\lambda$ expression is knocked down are not only viable and fertile, but also display a normal hyper-mutation pattern (58).

As well as causing inflammation, DSS influences cell proliferation and has physiological effects on florid epithelial cells in colitis, because it has colonic tumor promoter activity (45). Therefore, anti-inflammatory agents are expected to suppress DNA replication/repair/recombination in nuclei in relation to the action of DSS. Because pol $\lambda$ is a DNA repair-related pol (49), the molecular target of the VK quinone derivatives, such as NQ, is in good agreement with this expected mechanism of anti-inflammatory agents. As a result, any inhibitor of DNA repair-related pol $\lambda$ might also be an inflammatory suppressor.

\section{Conclusion}

This review summarizes data showing that a positive correlation between mammalian pol inhibitory activity and the anti-inflammatory response. The inflammatory mediators, such as LPS and DSS, induce ROS and ROS mediates oxidative DNA damage. As shown in Fig. 6, DNA repair-related pols, such as pol $\lambda$, induce the protein expression and increase the activity of these pols to repair the damaged DNA. Furthermore, we consider that pol $\lambda$ has effects on the inflammatory responses, such as TNF- $\alpha$ production, NF- $\kappa B$ activation, secretion of cytokines, damage of tissues and cell death. These phenomena suggest that the inhibition of pol $\lambda$ activity is related to the anti-inflammation and pol $\lambda$ inhibitors, some VKs and their related quinone derivatives, such as NQ, could be chemotherapeutic drugs for inflammatory diseases.

\section{Acknowledgements}

Y.M. acknowledges Grants-in-Aid from Scientific Research (C) (no. 24580205) from MEXT (Ministry of Education, Culture, Sports, Science and Technology, Japan), Takeda Science Foundation (Japan) and the Nakashima Foundation (Japan). This study was supported in part by grants for the MEXTSupported Program for the Strategic Research Foundation at Private Universities, 2012-2016 (Y.M.), the Global COE Program 'Global Center of Excellence for Education and Research on Signal Transduction Medicine in the Coming Generation' from MEXT (T.A. and M.Y.) and for the Young Researchers Training Program for Promoting Innovation from MEXT through the Special Coordination Fund for Promoting Science and Technology (S.N. and T.A.).

\section{References}

1. Furie B and Furie BC: Molecular basis of vitamin K-dependent $\gamma$-carboxylation. Blood 75: 1753-1762, 1990.

2. Suttie JW: Synthesis of vitamin K-dependent proteins. FASEB J 7: 445-452, 1993

3. Shearer MJ: Role of vitamin K and Gla proteins in the pathophysiology of osteoporosis and vascular calcification. Curr Opin Clin Nutr Metab Care 3: 433-438, 2000.

4. Ohsaki Y, Shirakawa H, Hiwatashi K, Furukawa Y, Mizutani T and Komai M: Vitamin K suppresses lipopolysaccharide-induced inflammation in the rat. Biosci Biotechnol Biochem 70: 926-932, 2006.

5. Seegers WH and Bang NU (eds): Blood Clotting Enzymology. Academic Press, New York, NY, 1967. 
6. Elder SJ, Haytowitz DB, Howe J, Peterson JW and Booth SL: Vitamin K contents of meat, dairy, and fast food in the U.S. diet J Agric Food Chem 54: 463-467, 2006.

7. Tsukamoto $\mathrm{Y}$, Ichise $\mathrm{H}$, Kakuda $\mathrm{H}$ and Yamaguchi M: Intake of fermented soybean (natto) increases circulating vitamin K2 (menaquinone-7) and $\gamma$-carboxylated osteocalcin concentration in normal individuals. J Bone Miner Metab 18: 216-222, 2000.

8. Suttie JW: The importance of menaquinone in human nutrition. Annu Rev Nutr 15: 399-417, 1995.

9. Booth SL: Dietary vitamin K guidance: an effective strategy for stable control of oral anticoagulation? Nutr Rev 68: 178-181, 2010.

10. Billeter M, Bolliger W and Martius C: Untersuchungen uber die umwandlung von verfutterten K-vitamin durch austausch der seitenkette und die rolle der darmbakterien hierbei. Biochem Z 340: 290-303, 1964 (In German).

11. Davidson RT, Foley AL, Engelke JA and Suttie JW: Conversion of dietary phylloquinone to tissue menaquinone- 4 in rats is not dependent on gut bacteria. J Nutr 128: 220-223, 1998.

12. Budavari S, O'Neil MJ, Smith A and Heckelman PE (eds): The Merck Index. Merck \& Co. Inc., Rahway, NJ, 1989.

13. Taggart WV and Matschiner JT: Metabolism of menadione6,7-3H in the rat. Biochemistry 8: 1141-1146, 1969.

14. Monks TJ, Hanzlik RP, Cohen GM, Ross D and Graham DG: Quinone chemistry and toxicity. Toxicol Appl Pharmacol 112: 2-16, 1992.

15. O'Brien PJ: Molecular mechanisms of quinone cytotoxicity. Chem Biol Interact 80: 1-41, 1991.

16. Bolton JL, Trush MA, Penning TM, Dryhurst G and Monks TJ: Role of quinones in toxicology. Chem Res Toxicol 13: 135-160, 2000.

17. Cho AK, Schmitz DA, Ying Y, Rodriguez CE, DiStefano EW, Kumagai Y, Miguel A, Eiguren A, Kobayashi T, Avol E and Froines JR: Determination of four quinones in diesel exhaust particles, SRM 1649a, and atmospheric PM2.5. Aerosol Sci Technol 38: 68-81, 2004

18. Kornberg A and Baker TA: DNA replication. Chaprter 6. 2nd edition. W.D. Freeman and Co., New York, NY, pp197-225, 1992.

19. Hubscher U, Maga G and Spadari S: Eukaryotic DNA polymerases. Annu Rev Biochem 71: 133-163, 2002.

20. Bebenek K and Kunkel TA: DNA repair and replication. Adv Protein Chem 69: 137-165, 2004.

21. Takata K, Shimizu T, Iwai S and Wood RD: Human DNA polymerase N (POLN) is a low fidelity enzyme capable of error-free bypass of 5S-thymine glycol. J Biol Chem 281: 23445-23455, 2006.

22. Loeb LA and Monnat RJ Jr: DNA polymerases and human disease. Nat Rev Genet 9: 594-604, 2008

23. Mizushina Y, Tanaka N, Yagi H, Kurosawa T, Onoue M, Seto H, Horie T, Aoyagi N, Yamaoka M, Matsukage A, Yoshida S and Sakaguchi K: Fatty acids selectively inhibit eukaryotic DNA polymerase activities in vitro. Biochim Biophys Acta 1308: 256-262, 1996

24. Mizushina Y, Yoshida S, Matsukage A and Sakaguchi K: The inhibitory action of fatty acids on DNA polymerase $\beta$. Biochim Biophys Acta 1336: 509-521, 1997.

25. Mizushina Y, Motoshima H, Yamaguchi Y, Takeuchi T, Hirano K, Sugawara F and Yoshida H: 3-O-methylfunicone, a selective inhibitor of mammalian Y-family DNA polymerases from an Australian sea salt fungal strain. Mar Drugs 7: 624-639, 2009.

26. Sakaguchi K, Sugawara F and Mizushina Y: Inhibitors of eukaryotic DNA polymerases. Seikagaku 74: 244-251, 2002.

27. Mizushina Y: Specific inhibitors of mammalian DNA polymerase species. Biosci Biotechnol Biochem 73: 1239-1251, 2009.

28. Mizushina Y: Screening of novel bioactive compounds from food components and nutrients. J Jpn Soc Nutr Food Sci 64: 377-384, 2011.

29. Mizushina Y, Yonezawa Y and Yoshida Y: Selective inhibition of animal DNA polymerases by fat-soluble vitamins A, D, E and $\mathrm{K}$ and their related compounds. Curr Enzyme Inhibition 3: 61-75, 2007.

30. Sasaki R, Suzuki Y, Yonezawa Y, Ota Y, Okamoto Y, Demizu Y, Huang P, Yoshida H, Sugimura K and Mizushina Y: DNA polymerase $\gamma$ inhibition by vitamin $\mathrm{K}_{3}$ induces mitochondriamediated cytotoxicity in human cancer cells. Cancer Sci 99: 1040-1048, 2008.

31. Matsubara K, Kayashima T, Mori M, Yoshida H and Mizushina Y: Inhibitory effects of vitamin $\mathrm{K}_{3}$ on DNA polymerase and angiogenesis. Int J Mol Med 22: 381-387, 2008.
32. Tanaka S, Nishiumi S, Nishida M, Mizushina Y, Kobayashi K, Masuda A, Fujita T, Morita Y, Mizuno S, Kutsumi H, Azuma T and Yoshida M: Vitamin $\mathrm{K}_{3}$ attenuates lipopolysaccharideinduced acute lung injury through inhibition of nuclear factor- $\kappa \mathrm{B}$ activation. Clin Exp Immunol 160: 283-292, 2010.

33. Chinzei R, Masuda A, Nishiumi S, Nishida M, Onoyama M, Sanki T, Fujita T, Moritoh S, Itoh T, Kutsumi H, Mizuno S, Azuma $\mathrm{T}$ and Yoshida M: Vitamin $\mathrm{K}_{3}$ attenuates ceruleininduced acute pancreatitis through inhibition of the autophagic pathway. Pancreas 40: 84-94, 2011.

34. Mizushina Y, Maeda J, Irino Y, Nishida M, Nishiumi S, Kondo Y, Nishio K, Kuramochi K, Tsubaki K, Kuriyama I, Azuma T, Yoshida $\mathrm{H}$ and Yoshida M: Effects of intermediates between vitamins $\mathrm{K}(2)$ and $\mathrm{K}(3)$ on mammalian DNA polymerase inhibition and anti-inflammatory activity. Int J Mol Sci 12: 1115-1132, 2011.

35. Kobayashi K, Nishiumi S, Nishida M, Hirai M, Azuma T, Yoshida H, Mizushina Y and Yoshida M: Effects of quinone derivatives, such as 1,4-naphthoquinone, on DNA polymerase inhibition and anti-inflammatory action. Med Chem 7: 37-44, 2011.

36. Aoganghua A, Nishiumi S, Kobayashi K, Nishida M, Kuramochi K, Tsubaki K, Hirai M, Tanaka S, Azuma T, Yoshida H, Mizushina Y and Yoshida M: Inhibitory effects of vitamin $\mathrm{K}_{3}$ derivatives on DNA polymerase and inflammatory activity. Int J Mol Med 28: 937-945, 2011.

37. Huang TT and Wuerzberger-Davis SM: Sequential modification of NEMO/IKKÁ by SUMO-1 and ubiquitin mediates NF- $\mathrm{KB}$ activation by genotoxic stress. Cell 115: 565-576, 2003.

38. Hayden M and Ghosh S: Signaling to NF- $\kappa$ B. Genes Dev 18: 2195-2224, 2004.

39. Bonizzi $\mathrm{G}$ and Karin M: The two NF- $\kappa \mathrm{B}$ activation pathways and their role in innate and adaptive immunity. Trends Immunol 25: 280-288, 2004

40. Wajant H, Pfizenmaier K and Scheurich P: Tumor necrosis factor signaling. Cell Death Differ 10: 45-65, 2003.

41. Elson CO, Sartor RB, Tennyson GS and Riddell RH: Experimental models of inflammatory bowel disease. Gastroenterology 109: 1344-1367, 1995

42. Aggarwal BB: Signalling pathways of the TNF superfamily: a double-edged sword. Nat Rev Immunol 3: 745-756, 2003.

43. Rahman I, Biswas SK and Kirkham PA: Regulation of inflammation and redox signaling by dietary polyphenols. Biochem Pharmacol 72: 1439-1452, 2006.

44. Corda S, Laplace C, Vicaut E and Duranteau J: Rapid reactive oxygen species production by mitochondria in endothelial cells exposed to tumor necrosis factor- $\alpha$ is mediated by ceramide. Am J Respir Cell Mol Biol 24: 762-768, 2001.

45. Cooper HS, Murthy SN, Shah RS and Sedergran DJ: Clinicopathologic study of dextran sulfate sodium experimental murine colitis. Lab Invest 69: 238-249, 1993.

46. Bhattacharyya S, Dudeja PK and Tobacman JK: ROS, Hsp27, and IKK $\beta$ mediate dextran sodium sulfate (DSS) activation of I $\mathrm{B} \alpha, \mathrm{NF} \kappa \mathrm{B}$, and IL-8. Inflamm Bowel Dis 15: 673-683, 2009.

47. Mizushina Y, Hirota M, Murakami C, Ishidoh T, Kamisuki S, Shimazaki N, Takemura M, Perpelescu M, Suzuki M, Yoshida H, Sugawara F, Koiwai O and Sakaguchi K: Some anti-chronic inflammatory compounds are DNA polymerase $\lambda$-specific inhibitors. Biochem Pharmacol 66: 1935-1944, 2003.

48. Mizushina Y, Takeuchi T, Kuramochi K, Kobayashi S, Sugawara F, Sakaguchi K and Yoshida H: Study on the molecular structure and bio-activity (DNA polymerase inhibitory activity, anti-inflammatory activity and anti-oxidant activity) relationship of curcumin derivatives. Curr Bioactive Compounds 3: 171-177, 2007.

49. Garcia-Diaz M, Bebenek K, Sabariegos R, Dominguez O, Rodriguez J, Kirchhoff T, Garcia-Palomero E, Picher AJ, Juarez R, Ruiz JF, Kunkel TA and Blanco L: DNA polymerase $\lambda$, a novel DNA repair enzyme in human cells. J Biol Chem 277: 13184-13191, 2002.

50. Singhal RK and Wilson SH: Short gap-filling synthesis by DNA polymerase $\beta$ is processive. J Biol Chem 268: 15906-15911, 1993.

51. Matsumoto Y and Kim K: Excision of deoxyribose phosphate residues by DNA polymerase $\beta$ during DNA repair. Science 269: 699-702, 1995.

52. Sobol RW, Horton JK, Kuhn R, Gu H, Singhal RK, Prasad R, Rajewsky K and Wilson SH: Requirement of mammalian DNA polymerase- $\beta$ in base-excision repair. Nature 379: 183-186, 1996. 
53. Ramadan K, Shevelev IV, Maga G and Hubscher U: DNA polymerase $\lambda$ from calf thymus preferentially replicates damaged DNA. J Biol Chem 277: 18454-18458, 2002.

54. Sugo N, Aratani Y, Nagashima Y, Kubota Y and Koyama H: Neonatal lethality with abnormal neurogenesis in mice deficient in DNA polymerase $\beta$. EMBO J 19: 1397-1404, 2000.

55. Garcia-Diaz M, Bebenek K, Kunkel TA and Blanco L: Identification of an intrinsic 5'-deoxyribose-5-phosphate lyase activity in human DNA polymerase $\lambda$ : a possible role in base excision repair. J Biol Chem 276: 34659-34663, 2001.

56. Hirose F, Hotta Y, Yamaguchi M and Matsukage A: Difference in the expression level of DNA polymerase $\beta$ among mouse tissues: high expression in the pachytene spermatocyte. Exp Cell Res 181: 169-180, 1989.
57. Garcia-Diaz M, Dominguez O, Lopez-Fernandez LA, De Lera LT, Saniger ML, Ruiz JF, Parraga M, Garcia-Ortiz MJ, Kirchhoff T, Del Mazo J, Bernad A and Blanco L.. DNA polymerase $\lambda$, a novel DNA repair enzyme in human cells. J Mol Biol 301: 851-867, 2000.

58. Bertocci B, De Smet A, Flatter E, Dahan A, Bories JC, Landreau C, Weill JC and Reynaud CA: Cutting edge: DNA polymerases $\mu$ and $\lambda$ are dispensable for Ig gene hypermutation. J Immunol 168 : 3702-3706, 2002. 